\title{
FRAUDULENT CONCEALMENT AND THE DUTY TO DISCLOSE MEDICAL MISTAKES
}

\author{
GERALD ROBERTSON*
}

\begin{abstract}
The author examines recent case-law which suggests that, when a mistake is made in the course of medical treatment, the physician is under a legal duty to inform the patient of this. The significance of this development is discussed with particular reference to limitation periods in medical negligence cases.
\end{abstract}

\section{INTRODUCTION}

In recent years a great deal of attention has focused on the duty of a doctor to provide the patient with information prior to performing medical treatment: the concept of "informed consent". Very little, however, has been said about a related issue - how much information must a doctor give a patient after the treatment has been performed? In particular, if a mistake is made in the course of treatment (especially surgical treatment), is the doctor under a legal duty to inform the patient of this?'

Where a mistake is made in the course of a surgical operation, the doctor's duty to provide reasonable post-operative care requires that proper corrective measures be taken. This will often involve having to inform the patient that something has gone wrong, if this is not already apparent, in order to make the patient aware of the need for further treatment. If the patient is not told, and suffers injury as a result, the doctor is clearly liable. For example, in Melvin v. Graham ${ }^{2}$ a surgeon who cut into the patient's bladder during a herniotomy was held to have been negligent in not providing proper post-operative care to deal with potential complications arising from his mistake. Similarly, it has been held that failure to inform a patient that a sterilization operation has been unsuccessful, ${ }^{3}$ or that the tip of a hypodermic syringe has broken off during an injection and remains lodged in the patient's body, ${ }^{4}$ renders the doctor liable for any additional injuries suffered as a result of the patient not undergoing corrective treatment. ${ }^{s}$

A much more problematic situation arises where the doctor's failure to tell the patient what has happened does not cause any additional physical injury, but merely keeps the patient ignorant of a possible cause of action

- Of the Faculty of Law, University of Alberta.

1. For a discussion of the U.S. case-law see J. Vogel and R. Delgado, "To Tell the Truth: Physicians' Duty to Disclose Medical Mistakes" (1980) 28 U.C.L.A. L. Rev. 52.

2. [1973] D.R.S. 659 (Ont. H.C.).

3. Cryderman v. Ringrose [1978] 3 W.W.R. 481 (Alta. C.A.); see also Sciuiraga v. Powell, unreported, 18 May 1979 (Eng. Q.B.); affd. Court of Appeal Transcript [1980] 597, noted in G. Robertson, "Damages For Failed Abortion" (1980) 44 Mod. L. Rev. 215.

4. Gerber v. Pines (1934) 79 Sol. Jo. 13 (K.B.); but see Daniels v. Heskin [1954] I.R. 73 (S.C.) (doctor not negligent in failing to inform patient of presence of broken needle).

5. In Kueper v. McMullin (1986) 37 C.C.L.T. 318 (N.B.C.A.), the tip of a dental drill accidentally broke off and lodged in the plaintiff's tooth while the defendant-dentist was performing a root canal. The dentist tried unsuccessfully to remove the drill tip, and decided to seal the tooth. He did not inform the patient of what had happened. The patient's subsequent claim for damages was dismissed. The court held that the dentist ought to have informed the patient of what had happened, and discussed with her the alternative methods of dealing with the problem. However, the court concluded that, even if she had been told, the patient would have consented to having the tooth sealed with the drill tip inside. 
against the doctor. In many instances a patient who suffers injury during a surgical operation may only discover this (if at all) several years later. In view of the applicable limitation period in Alberta, it becomes especially important to consider whether the law imposes a duty on the doctor to inform the patient of what went wrong in the course of the operation. The recent decision of the English Court of Appeal in Lee v. South West Thames Regional Health Authority, ${ }^{6}$ and the Ontario case of Stamos v. Davies ' which follows it, suggest that a duty to disclose medical mistakes does exist.

\section{THE DUTY TO DISCLOSE MEDICAL MISTAKES}

In Lee a patient was transferred to a hospital administered by the Hillingdon Health Authority (Hillingdon). The transfer was undertaken by an ambulance provided by the South West Thames Regional Health Authority (Thames). While receiving treatment either in the ambulance or in the hospital, the patient suffered severe brain damage, probably due to a lack of oxygen. An action for damages was subsequently brought against Hillingdon. For the purposes of defending the claim, Hillingdon requested and obtained from Thames a report prepared by the ambulance crew. The patient's request for a copy of the report was refused by Thames, and so he applied to the court for an order that the report be disclosed.

The English Court of Appeal, in a judgment delivered by Sir John Donaldson, M.R., refused to make the order, on the ground that the report was privileged. However, the importance of the case lies in the concluding remarks of the Master of the Rolls. He observed that: ${ }^{8}$

\footnotetext{
The recent decision of the House of Lords in Sidaway v. Bethlem Royal Hospital Governors [1985] 1 All E.R. 643 . . . affirms that a doctor is under a duty to answer his patient's questions as to the treatment proposed ... Why, we ask ourselves, is the position any different if the patient asks what treatment he has in fact had? Let us suppose that a blood transfusion is in contemplation. The patient asks what is involved. He is told that a quantity of blood from a donor will be introduced into his system. He may ask about the risk of AIDS and so forth and will be entitled to straight answers. He consents. Suppose that, by accident, he is given a quantity of air as well as blood and suffers serious ill effects. Is he not entitled to ask what treatment he in fact received, and is the doctor and hospital authority not obliged to tell him, 'in the event you did not only get a blood transfusion. You also got an air transfusion'? Why is the duty different before the treatment from what it is afterwards?

If the duty is the same, then if the patient is refused information to which he is entitled, it must be for consideration whether he could not bring an action for breach of contract claiming specific performance of the duty to inform. In other words, whether the patient could not bring an action for discovery, albeit on a novel basis.
}

It is interesting to note that in Lee Sir John Donaldson was repeating what he had said extra-judicially two months earlier, in an address to the Medico-Legal Society. ${ }^{9}$ In that address he admitted that he was simply "flying a kite" with respect to his views on the duty to disclose medical mistakes. When asked by a member of the audience whether the law does

6. [1985] 2 All E.R. 385 (C.A.).

7. (1985) 21 D.L.R. (4th) 507 (Ont. H.C.).

8. Supra n. 6 at 389-390.

9. (1985) 53 Medico-Legal J. 148. 
say that doctors must inform their patients if something goes wrong, he replied, "the law does not say so yet". ${ }^{10}$ Two months later it did."

As was predicted by a leading English barrister, ${ }^{12}$ the kite flown by the Master of the Rolls did not stay in the air indefinitely. It landed in Ontario, in the judgment of Mr. Justice Kreever in Stamos v. Davies. ${ }^{13}$ This case arose out of a lung biopsy performed by the defendant, a surgeon, on the plaintiff. In the course of the procedure, the defendant punctured the plaintiff's spleen. The defendant informed the plaintiff that the biopsy would have to be done again, because he had not obtained what he wanted. When asked by the plaintiff what he had in fact obtained, the defendant replied "something else". The plaintiff's spleen subsequently had to be removed. The defendant was held liable for negligently puncturing the plaintiff's spleen. In addition, Mr. Justice Krever, relying on Lee, held that the defendant was in breach of duty in not telling the plaintiff what had happened. However, the court concluded that this breach of duty had not caused the plaintiff any additional loss.

It should be noted that in Lee the doctor's duty of disclosure after treatment was restricted to the situation where the patient asks for information. In the context of English law this restriction is understandable, given that the doctor's duty was viewed as a corollary of the House of Lords' decision in Sidaway v. Board of Governors of the Bethlem Royal Hospital ${ }^{14}$ dealing with "informed consent". In Sidaway the majority of the House of Lords, while holding that the duty to disclose information prior to treatment was determined according to the standard of the reasonable physician, emphasized that a doctor must answer any questions which the patient asks concerning the proposed treatment.

There is no reason why this restriction in Lee should be followed in Canada. Although the point was not discussed by Krever, J. in Stamos, in principle the doctor's duty to tell the patient what has happened should apply regardless of whether the patient asks. If, as is emphasized in Lee, the doctor's duty to give information is the same both before and after the treatment has been performed, the position in this country should be governed by the Supreme Court of Canada decision in Reibl v. Hughes. ${ }^{15}$

10. Id. at 162 .

11. This is not the first occasion on which an English judge has been in the enviable position of making his own extra-judicial predictions come true. In a case-note, (1965) 81 L.Q. Rev. 478, Mr. Robert Megarry (as he then was) predicted that, "within a decade or two", English law might well impose liability on a solicitor in respect of financial loss suffered by a beneficiary as a result of the solicitor's negligence in drafting the will. Fifteen years later liability was imposed, in the landmark decision in Ross v. Caunters [1980] Ch. 297. The judgment was delivered by Vice-Chancellor Megarry. See M. Litman and G. Robertson, "Solicitor's Liability for Failure to Substantiate Testamentary Capacity" (1984) 62 Can. Bar Rev. 457 at 461.

12. Whitfield, "The Meaning of Informed Consent" (1985) 54 Medico-Legal J. 11 at 21.

13. (1985) 21 D.L.R. (4th) 507 (Ont. H.C.). See also Hadley v. Allore (1985) 53 O.R. (2d) 419 (H.C.), in which the plaintiff alleged that, having performed a caesarean section, the defendants proceeded to sterilize her without her consent, by means of a tubal ligation. McKinlay, J. (at 424) observed obiter that the defendants were under a duty to inform the plaintiff not only that they had performed the tubal ligation, but also that the chances of being able to reverse it were poor.

14. [1985] A.C. 871, [1985] 1 All E.R. 643 (H.L.).

15. [1980] 2 S.C.R. 880, 114 D.L.R. (3d) 1 . 
This would mean that a doctor is under a duty to tell the patient what has happened if, in all the circumstances, a reasonable person in the patient's position would want to be told. It is difficult to conceive of a situation in which a reasonable patient who has suffered injury as a result of a surgical error would not want to be informed of this.

At first sight it may seem odd to view the duty to disclose what has happened as a corollary of the doctrine of informed consent. The duty arises after the treatment has been performed, by which time the patient's consent has already been obtained. However, the duty has much in common with the doctrine of informed consent, in that both stem from the patient's interest in self-determination. The patient "has a right to determine what shall be done with his own body";16 equally, he should have a right to know what has in fact been done.

The duty to disclose medical mistakes has significant, and potentially wide-ranging, implications. For example, as is suggested in Lee, it may assist a patient in obtaining access to medical records. There is usually no difficulty in obtaining discovery of such records under the Rules of Court. " However, this procedure applies only after legal proceedings have been commenced and pleadings have closed. ${ }^{18}$ Although legislation in Alberta provides a mechanism for obtaining hospital records prior to the commencement of an action, ${ }^{19}$ there is no equivalent procedure with respect to other medical records (for example, the office records of a general practitioner). The decision in Lee may well prove useful in this regard.

Another important aspect of the duty to disclose medical mistakes is that its breach can give rise to an independent cause of action. Thus, even where the original mistake is not a negligent one, the patient may still be able to recover damages for any additional loss suffered as a result of not being told of the mistake. ${ }^{20}$ As we have already seen, plaintiffs in a number of cases have recovered damages for physical injury suffered as a result of not being informed of the need for further treatment to correct a surgical error. ${ }^{21}$ This would extend to any additional financial loss and pain and suffering arising from the delay in having corrective treatment. ${ }^{22}$ As is aptly

16. Schloendorff v. Society of New York Hospital (1914) 211 N.Y. 125, per Cardozo J. at 129 130.

17. Alberta Rules of Court, rules 186-199, 209. See also E.I. Picard, Legal Liability of Doctors and Hospitals in Canada (Carswell, 2nd ed. 1984) Chapter 10.

18. Alberta Rules of Court, rule 186(2); see also Andree v. Misericordia General Hospital [1980] 2 W.W.R. 380 (Man. Q.B.).

19. Hospitals Act, R.S.A. 1980, c. H-11, s. 40(10); Mental Health Act, R.S.A. 1980, c. M-13, s. 37(9); see also Lindsay v. D.M. [1981] 3 W.W.R. 703 (Alta. C.A.).

20. In the leading American article on this issue, J. Vogel and R. Delgado, supra n. 1, suggest that the duty to disclose should apply only to negligent mistakes. However, the principles enunciated in Lee and Stamos are clearly broad enough to cover disclosure on non-negligent mistakes.

21. Melvin v. Graham, supra n. 2; Sciuriaga v. Powell, supra n. 3; Gerber v. Pines, supra n. 4.

22. This is analogous to the decision in Rivtow Marine v. Washington Iron Works (1973) 40 D.L.R. (3d) 530 (S.C.C.), in which the charterer of a crane manufactured by the defendants recovered damages for the additional economic loss suffered as a result of the defendants' failure to warn of defects in the crane as soon as these defects became known to the defendants. 
stated in one American article, ${ }^{23}$ the "passage of time may render corrective measures even more painful or difficult than they would have been had they been carried out more promptly.'

\section{AVOIDING THE LIMITATION DEFENCE}

\section{A. LIMITATION PERIODS IN MEDICAL NEGLIGENCE CASES}

By far the most important implication of the duty to disclose medical mistakes is its potential use in avoiding the limitation defence. In Alberta, section 55 of the Limitation of Actions Act ${ }^{24}$ states that an action against a physician $^{2 s}$ for negligence or malpractice ${ }^{26}$ by reason of professional services requested or rendered must be commenced within one year from the date when the professional services terminated in respect of the matter that is the subject of the complaint. The effect of this provision is that many patients are time-barred before they even realize that they have a cause of action, because the injurious consequences of the doctor's negligence do not develop, or do not become apparent, within the one year limitation period. As Professor McLaren explains:27

The classic situation is where the doctor in carrying out an operative procedure on the patient leaves a foreign object, for example a surgical swab, tubing or forceps, within the body which does not manifest its presence until much later. A second illustration is provided by the case where the physician in conducting an operation or course of treatment does the job carelessly or incompetently, and the adverse consequences are slow in developing. A third situation exists where a physician negligently examines a patient, fails to diagnose properly a medical problem and leaves the latter with the erroneous impression that he is medically sound, thus postponing necessary medical treatment.

\section{B. THE DISCOVERY RULE}

The injustice evident in these examples could be avoided if section 55 were held to be subject to the Supreme Court of Canada decision in City of Kamloops v. Nielsen. ${ }^{28}$ In that case it was held that a cause of action in negligence arises only when the plaintiff discovers, or ought with reasonable diligence to have discovered, the injury. Nielsen has received a rather cool reception in Alberta, partly as a result of the decision of the Alberta Court of Appeal in Costigan v. Ruzicka ${ }^{29}$ In Costigan the Court of Appeal rejected the discovery rule, but its decision was per incuriam ${ }^{30}$ since it was rendered in ignorance of the Supreme Court's judgment in Nielsen (which had been handed down only one week earlier). Nevertheless, the fact that the Supreme Court later denied leave to appeal in Costigan led one Alberta judge to conclude that Costigan, and not Nielsen, represents the law of

23. J. Vogel and R. Delgado, supra n. 1 at 80.

24. R.S.A. 1980, c. L-15.

25. Certain other health care professionals are also included.

26. This has been held to include actions for battery and breach of contract - see most recently Hadley v. Allore (1985) 53 O.R. (2d) 419 (H.C.) and Vincent v. Hall (1985) 49 O.R. (2d) 701 (H.C.) and the cases discussed therein.

27. McLaren, "Of Doctors, Hospitals and Limitations - 'The Patient's Dilemma'" (1973) 11 Osgoode Hall L.J. 85 at 89-90; see also Picard, supra n. 17 at 248-251.

28. [1984] 2 S.C.R. 2, 10 D.L.R. (4th) 641 .

29. [1984] 6 W.W.R. 1 (Alta. C.A.), leave to appeal refused [1984] 6 W.W.R. 1 xiii (S.C.C.).

30. See J. Irvine, "Case Comment: Ruzicka v. Costigan" (1985) 31 C.C.L.T. 306. 
Alberta. ${ }^{31}$ Moreover, some courts ${ }^{32}$ and commentators ${ }^{33}$ have taken the view that Nielsen is not a rule of general application, and is restricted to cases of latent damage to buildings. However, the position has now been clarified by the Supreme Court of Canada in Central Trust Co. v. Rafuse, ${ }^{34}$ in which it was held that the discovery rule enunciated in Nielsen is a rule of general application. In light of this decision, there can be little doubt that Nielsen represents the law of Alberta.

Although Nielsen is the key to avoiding injustice in cases of latent injury, the key does not seem to fit when one is faced with section 55 of the Alberta Limitation of Actions Act. The language of that section is clear - the limitation period starts to run when the professional services terminate, regardless of when the cause of action arises. Thus, the fact that Nielsen postpones the accrual of the cause of action is irrelevant in cases to which section 55 applies. ${ }^{35}$ This view finds support in a number of decisions. For example, in Workman v. Greer ${ }^{36}$ the Manitoba Court of Appeal rejected the submission that the Manitoba equivalent of section 55 was subject to the common law discovery rule. Moreover, in a number of post-Nielsen cases (including a Supreme Court of Canada decision) which have applied other provinces' equivalent of section 55, the Nielsen case has not been discussed or even cited. ${ }^{37}$

\section{FRAUDULENT CONCEALMENT}

Unlike the decision in Nielsen, the duty to disclose medical mistakes does assist the plaintiff in avoiding the section 55 limitation defence. It does so by means of the concept of fraudulent concealment. Section 57 of the Alberta Limitation of Actions Act provides that:

If the existence of a cause of action to which this Part applies has been concealed by the fraud of the person setting up this Part as a defence, the cause of action shall for the purposes of this Part be deemed to have arisen when the fraud was first known or discovered.

At first sight it may appear that this provision does not apply to section 55, for the same reason that Nielsen is inapplicable. It postpones the accrual of the cause of action, but this is immaterial since the limitation period in

31. Grandwood Flooring Western v. Prism Construction Co. (1986) 43 Alta. L.R. (2d) 337 (Q.B.).

32. Brent v. R. [1985] 5 W.W.R. 383 (Fed. T.D.); Bera v. Marr [1986] 3 W.W.R. 442 (B.C.C.A.). But see Consumers Glass Co. v. Foundation Co. of Canada (1985) 20 D.L.R. (4th) 126 (Ont. C.A.).

33. B. Feldthusen, (1985) 30 McGill L.J. 539; Rafferty, (1986) 6 Oxford J. Leg. Studies 464. But J. Irvine, (1984) 29 C.C.L.T. 185 and D. Gibson, (1985) 7 Supreme Court L. Rev. 387 take the view that Nielsen is a rule of general application.

34. (1986) 37 C.C.L.T. 117 (S.C.C.).

35. Nielsen would, however, apply to $s .56$ of the Act, which provides that an action against a hospital must be commenced "within one year after the cause of action arose".

36. (1978) 90 D.L.R. (3d) 676 (Man. C.A.).

37. Martin v. Perrie [1986] I S.C.R. 41, 24 D.L.R. (4th) 1; McMaster v. Chang (1985) 33 Man. R. (2d) 54 (Q.B.), affd. 34 Man. R. (2d) 161 (C.A.); Roberts v. Perkins (1985) 51 Nfld. \& P.E.I.R. 305 (Nfld. T.D.); Sawh v. Petrie (1986) 72 N.S.R. (2d) 316 (S.C.T.D.); Elliot v. Saskatoon [1985] 5 W.W.R. 22 (Sask. Q.B.), affd. [1986] 3 W.W.R. 575 (C.A.). 
section 55 is not linked to the cause of action. ${ }^{38}$ However, section 55 is expressly stated as being subject to section 57 . For this proviso to have any meaning, it must follow that fraudulent concealment postpones the running of the limitation period in section $55 .^{39}$

The classic definition of "fraudulent concealment" is contained in the following dictum of Lord Evershed in Kitchen v. R.A.F. Association: ${ }^{40}$
It is now clear, however, that the word "fraud" in s. 26(b) of the Limitation Act, 1939, is by no means limited to common law fraud or deceit. Equally, it is clear . . . that no degree of moral turpitude is necessary to establish fraud within the section. What is covered by equitable fraud is a matter which Lord Hardwicke did not attempt to define two hundred years ago, and I certainly shall not attempt to do so now, but it is, I think, clear that the phrase covers conduct which, having regard to some special relationship between the parties concerned, is an unconscionable thing for the one to do towards the other.

This passage has been adopted in numerous Canadian cases, including decisions of the Supreme Court of Canada ${ }^{41}$ and the Alberta Court of Appeal..$^{42}$ It is also well established that there can be fraudulent concealment by virtue of an omission, as opposed to a positive act..$^{43}$ In the words of Lord Denning:44
In order to show that [the defendant] "concealed" the right of action by "fraud", it is not necessary to show that he took active steps to conceal his wrongdoing or his breach of contract. It is sufficient that he knowingly committed it and did not tell the [plaintiff] anything about it. He did the wrong or committed the breach secretly. By saying nothing, he keeps it secret. He conceals the right of action. He conceals it by "fraud" as those words have been interpreted in the cases.

The existence of a legal duty to disclose medical mistakes, as established in Lee v. South West Thames Regional Health Authority ${ }^{45}$ and Stamos v. Davies, ${ }^{46}$ lends considerable support to an argument based on fraudulent concealment. The doctor is under a legal duty to inform the patient of what has happened; the doctor knowingly disregards this duty and remains silent, thereby concealing from the patient the existence of a possible cause of action. It is submitted that, in view of the duty to disclose and of the special relationship between doctor and patient, such conduct is "unconscionable" and constitutes fraudulent concealment.

The position is similar to that of a lawyer who makes a mistake which causes, or which may cause, the client financial loss. In such circumstances

38. This reasoning was applied in Tremeer v. Black [1924] 2 D.L.R. 520 (Sask. C.A.); see also Pierce v. Strathroy Hospital (1924) 27 O.W.N. 180 (H.C.). However, in Winn v. Alexander and the Soldiers' Memorial Hospital [1940] O.W.N. 238 (H.C.) the defendant's motion to have the plaintiff's claim struck out as statute-barred was dismissed on the ground that the plaintiff's argument with respect to fraudulent concealment raised a triable issue.

39. Professor McLaren, supra n. 27 at 94, states (with reference to the Alberta statute) that it is "clear that the statutory exceptions for fraud . . . apply to the malpractice suits."

40. [1958] 2 All E.R. 241 at 249 (C.A.).

41. Guerin v. The Queen [1984] 2 S.C.R. 335.

42. Joncas v. Pennock (1962) 32 D.L.R. (2d) 756 (Alta. C.A.).

43. King v. Victor Parsons \& Co. [1973] 1 All E.R. 206 (C.A.); Guerin v. The Queen, supra n. 4l; Revelstoke Companies v. Lindsay (1981) 17 Alta. L.R. (2d) 339 (Q.B.); Vienneau v. Arsenault (1982) 41 N.B.R. (2d) 82 (C.A.); UBAF Ltd. v. European American Banking Corporation [1984] 2 W.L.R. 508 (C.A.). Note, however, that the omission must be intentional, and not merely careless or reckless - see Sawh v. Petrie, supra n. 37.

44. King v. Victor Parsons \& Co., supra n. 43 at 209.

45. [1985] 2 All E.R. 385 (C.A.).

46. (1985) 21 D.L.R. (4th) 507 (Ont. H.C.). 
lawyers are under an ethical ${ }^{47}$ and legal ${ }^{48}$ duty to inform their clients of what has happened and to advise them to obtain independent legal advice. Breach of this duty constitutes fraudulent concealment of a cause of action. For example, in Vienneau v. Arsenault ${ }^{49}$ a lawyer's negligence resulted in his client's personal injury claim being dismissed for want of prosecution. By the time the client discovered this, the limitation period for an action against his lawyer had expired. The New Brunswick Court of Appeal held that the lawyer's failure to inform his client of what had happened amounted to fraudulent concealment, which postponed the commencement of the limitation period.

The decisions in Lee and Stamos place the doctor in the same position as the lawyer with respect to disclosing that a mistake has been made. This development could prove to be highly significant, particularly in provinces (such as Alberta) where the limitation period in an action against a doctor is not subject to a discovery rule.

Support for this approach can also be found in a recent decision of the Ontario Divisional Court. In Branche v. MacArthur ${ }^{\text {so }}$ the plaintiff sued two doctors, alleging negligence in the performance of an operation which resulted in damage to facial nerves. Prior to the operation, the plaintiff had been led to believe that the two doctors named as defendants would be the ones to perform the operation. In fact, unknown to the plaintiff, a third doctor also took part in the operation. When the plaintiff later discovered this, she applied to add the third doctor as a defendant. The application was dismissed by a Master on the ground, inter alia, that the limitation period had expired. The Master's decision was reversed by the Divisional Court. White, J. held that: ${ }^{31}$

I would find, at least in a prima facie sense, and of course subject to any contrary finding, made on all the evidence by a trial judge, that the unfairness resulting from the plaintiff having been led to believe that she would be operated on by Dr. McKee and Dr. MacArthur, and Dr. McDonald having surreptitiously taken part in that operation, and no one having disclosed to her his activity in the operation, notwithstanding a significant mishap that occurred during the operation, are sufficient to attract application of the doctrine of fraud, as a basis for extending the limitation period. I use the term fraud, as used in equity, that is as requiring no degree of moral turpitude, but as including conduct "which, having regard to some special relationship between the two parties concerned, is an unconscionable thing for the one to do towards the other ..."

47. Canadian Bar Association, Code of Professional Conduct (1974) 9.

48. Vienneau v. Arsenault, supra n. 43.

49. Supra n. 43.

50. (1986) 30 D.L.R. (4th) 301 (Ont. Div. Ct.).

51. Id. at 310. 


\section{CONCLUSION}

Until such time as it is amended, ${ }^{52}$ or perhaps successfully challenged under the Charter, ${ }^{33}$ section 55 of the Limitation of Actions Act will continue to cause grave injustice in cases of medical malpractice. That injustice stems, not so much from the fact that the limitation period is only one year, but rather from the fact that its commencement is not linked to the accrual of the cause of action. The provision therefore falls outside the scope of the discovery rule enunciated in City of Kamloops v. Nielsen, ${ }^{54}$ and we are faced with "the injustice of a law which statute-bars a claim before the plaintiff is even aware of its existence."ss Indeed, section 55 may cause even greater injustice: a patient may be time-barred before the cause of action even arises. For example, in many instances of medical negligence, injury to the patient may not occur until after one year has expired since the termination of professional services. Such a patient would be in the ludicrous position of not being able to sue during the one year period (because there is no cause of action), nor after it (because the action is timebarred). ${ }^{36}$

The duty to disclose medical mistakes provides a means of mitigating this injustice, at least in cases where the doctor knows that a mistake has been made. Occasionally, judges tend to be suspicious of what they perceive to be artificial "devices" created to remedy injustice in the law. However, the duty to disclose medical mistakes is not simply a remedial "device". It is based on sound legal principle, and parallels the duty imposed on lawyers. It reflects the importance of the patient's interest in self-determination, an importance recognized and emphasized by the Supreme Court of Canada in Reibl v. Hughes. ${ }^{57}$ Now that the duty to disclose medical mistakes has received support from the English Court of Appeal ${ }^{58}$ and the Ontario High Court, ${ }^{59}$ it may well gain recognition in other Canadian provinces.

It is submitted that if a doctor knowingly makes a mistake which causes, or which may cause, injury to the patient, the doctor is under a legal duty to inform the patient. Failure to discharge this duty constitutes fraudulent concealment, thereby postponing the running of the limitation period.

52. It should be noted that in its recent Discussion Paper on Limitations (September 1986), the Alberta Institute of Law Research and Reform has proposed fundamental changes to the law of limitations. If implemented, these proposals would remove the special provisions relating to malpractice claims.

53. See Streng v. Winchester (Twp.) (1986) 37 C.C.L.T. 296 (Ont. H.C.), in which the three months limitation period in the Municipal Act, R.S.O. 1980, c. 302, s. 284(2) was held to violate s. 15(1) of the Canadian Charter of Rights and Freedoms.

54. [1984] 2 S.C.R. 2, 10 D.L.R. (4th) 641.

55. Id. per Wilson J. at 685 (D.L.R.).

56. See, e.g., Workman v. Greer (1978) 90 D.L.R. (3d) 676 (Man. C.A.); Whiston v. Deane (1979) 95 D.L.R. (3d) 184 (B.C.S.C.). Both cases deal with failed sterilization operations.

57. [1980] 2 S.C.R. 880, 114 D.L.R. (3d) 1.

58. Lee v. South West Thames Regional Health Authority [1985] 2 All E.R. 385 (C.A.).

59. Stamos v. Davies (1985) 21 D.L.R. (4th) 507 (Ont. H.C.). 